\title{
THE INFLUENCE OF AGRICULTURE ON THE CHEMICAL COMPOSITION OF GRAY SOILS FROM CENTRAL MOLDOVA
}

\section{$\underline{\text { Tamara Leah }}^{1}$}

1 "Nicolae Dimo" Institute of Soil Science, Agrochemistry and Soil Protection, Chisinau2070, Ialoveni str.100, tamaraleah09@gmail.com, Republic of Moldova

\begin{abstract}
As a result of agricultural use of forest gray soils as arable land, instead fallow horizon Ao and partly horizons A1 and A2 are formed arable Ap horizon. Prolonged use of gray soils in agriculture led to their degradation, manifested by decreasing of organic matter due to its mechanical destruction of valuable agronomic structure in the soil tillage process. Gray forest soils are characterized by a clear differentiation of total chemical composition in the genetic horizons. The mineral part of typical gray soil is composed of silicates and sesquioxides. In the composition of researched soils is predominate silica compounds $\left(\mathrm{SiO}_{2}\right)$, which make up 70$77 \%$. In the arable gray soil the $\mathrm{SiO}_{2}$ content is higher by $3.56 \%$ in humiferous soil layer than in virgin forest gray soil. The vertical distribution of $\mathrm{SiO}_{2}$ in the soil profile has an accumulative characteristic in humiferous horizon and partial in the parental rock. Share of oxides of $\mathrm{Mg}, \mathrm{Ti}$, $\mathrm{S}, \mathrm{P}, \mathrm{K}$ and $\mathrm{Na}$ constitute an insignificant part. According relatively content in the gray soils the oxides are located: $\mathrm{SiO}_{2} \rightarrow \mathrm{Al}_{2} \mathrm{O}_{3} \rightarrow \mathrm{Fe}_{2} \mathrm{O}_{3} \rightarrow \mathrm{K}_{2} \mathrm{O} \rightarrow \mathrm{Na}_{2} \mathrm{O} \rightarrow \mathrm{CaO} \rightarrow \mathrm{MgO} \rightarrow \mathrm{TiO}_{2} \rightarrow \mathrm{SO}_{3} \rightarrow$ $\mathrm{MnO} \rightarrow \mathrm{P}_{2} \mathrm{O}_{5}$. Utilization of forest gray soil in agriculture led to changes in their chemical composition in the upper humiferous horizon and intensification of eluvial process in them. To improve fertility of arable gray soils is necessary to increase organic matter in arable layer, to remediate structure and combat erosion process.
\end{abstract}

Keywords: arable, chemical composition, gray soil, Moldova, sesquioxides

\section{Introduction}

Genesis of gray forest soils is associated with broadleaf forests, where much developed the grass cover. In these circumstances, in gray forest soils occurs manifestation of two main processes that determine the characteristics of these soils. The first of these processes is obliged to action of descending currents of precipitation entering in the soil, and its result is the removal of a number of weathering and genesis products from upper to bottom soil layers or from the soil as a whole into the underlying layers of the soil-forming rocks.

The second process is associated with an accumulation of vegetation activity that its root system absorbs a significant amount of minerals from the entire thickness of soil and lay by them in the form of organic residues primarily in the upper layer of the soil or on its surface. The result is an accumulation of humus in the upper layers of soil and some mineral and organic-mineral substances, in particular associated with calcium humus. Therefore, in conditions of forest-steppe (in most cases) not prevails podzolic soil-forming, but other - soddy soil-forming process [1, 2].

Typical gray forest soils of Central Moldova were formed under oak forests with developed grassy coating. Main features of gray clayey-loamy soils are: levigation of carbonates up to $80-90 \mathrm{~cm}$ depth; formation of the illuvial carbonatic horizon - very compacted and dry in the bottom of profile, with a high carbonates content $(20-30 \%)$, in the form of concretions, bieloglasca, veins; large variation of texture differentiation 
in soil profiles; combination of eluvial-Illuvial process of clay migration with alteration process "in situ" of mineral part of these soils. The main degradation factors of gray soil are dehumification, destructuring and secondary compacting of arable layer as a result of their inclusion in the agricultural circuit and contrast climate regime in their spreading area. Their natural vegetation is disturbed; chemical composition in the upper layers is changed, so soil is exposed to water erosion process [3, 4].

\section{Materials and Methods}

To determine the agriculture use influence on the gray virgin soils were studied two soil profiles: gray soil, located in the forest (as standard) and gray soil used as arable for field crops. Global (total) analysis of soil is the result of determining the elemental composition of the mineral part of the soil. $\mathrm{Al}_{2} \mathrm{O}_{3}$ and $\mathrm{Fe}_{2} \mathrm{O}_{3}$ oxides called sesquioxides because for one atom of iron and aluminum they account one and a half oxygen atom. Thus, the method consists in the transformation of insoluble compounds in the soluble form, usually by melting carbonates, that serves to determine the $\mathrm{Si}, \mathrm{Al}, \mathrm{Fe}, \mathrm{Ti}, \mathrm{Ca}, \mathrm{Mg}$, $\mathrm{Mn}, \mathrm{Na}, \mathrm{K}$ and $\mathrm{P}$ - elements that make up "main portion" of elemental analysis of soil [5]. Total analysis of the chemical composition is necessary as the initial stage of research and defines the direction of research and additional measurements, which could lead to solving problems on soil genesis and anthropogenic changes.

\section{Results and Discussion}

Gray forest soils in natural condition of Moldova are characterized by a clear differentiation of the total chemical composition of genetic horizons. Arable gray soil lost this characteristic and was exposed to degradation processes.

Silicium In the investigated gray soils the greatest part of the soil weight accounted silica compounds $\left(\mathrm{SiO}_{2}\right)$. The total content of $\mathrm{SiO}_{2}$ in the surface horizon of gray soil varies between $70-77 \%$. Distribution of $\mathrm{SiO}_{2}$ in the soil profile is characteristic for each soil type and characterized soil-genesis process. Large silica content in the soil is due to the wide spread of quartz compounds in the rock, which is a part of simple and complex silicates, secondary soil minerals and clays. Silicium is accumulated in the soil in the quartz form and amorphous silicic acid containing variable amounts of adsorbed water and in the form of secondary minerals [1].

Accumulation of silica associated with the process of weathering of rocks and minerals, with the life of higher and lower plants. In the gray arable soil $\mathrm{SiO}_{2}$ content in humeferous horizon is higher by $3.56 \%$ than in gray forest soil. Their vertical distribution in the soil profile has an accumulative character in the humiferous horizon and partial in the parental rock (Table 1).

The $\mathrm{Al}_{2} \mathrm{O}_{3}$ and $\mathrm{Fe}_{2} \mathrm{O}_{3}$ on quantitative content in the soil are in second placing after $\mathrm{SiO}_{2}$, since alumino-silicates and ferro-silicates much common in the earth's crust.

Aluminum is the most widespread metal in nature and enters into the composition of clays. Aluminum is closely linked to the oxygen and silicon in the alumino-silicate, of which it consists the earth's crust and by chemical degradation is converted into clay, which basis consist kaolin [6]. The total content of $\mathrm{Al}_{2} \mathrm{O}_{3}$ in the surface soil horizon varies from $12.4 \%$ in the virgin gray soil, to $14.0 \%$ in arable gray soil. This indicates the relative accumulation of silicates and alumino-silicates in the typical arable gray soils resistant to weathering. Down by the soil profile $\mathrm{Al}_{2} \mathrm{O}_{3}$ content usually increases - to $16.7 \%$ in horizon $\mathrm{B}_{2}$ of arable soil. 
Iron is a part of various minerals. In soils iron is a secondary component of clay minerals. The total content of $\mathrm{Fe}_{2} \mathrm{O}_{3}$ in the surface layer $(A)$ of gray soils ranges from 4.14-6.40\%. Deep into the soil profile iron content in gray forest soils increases, up to $6-8 \%$ in $\mathrm{BC}$ and $\mathrm{C}$ horizons.

Table 1. The global analysis of gray soils (\%, calcinated soil)

\begin{tabular}{|c|c|c|c|c|c|c|c|c|c|c|c|c|}
\hline $\begin{array}{c}\text { Genetic } \\
\text { horizon } \\
\text { and depth, } \\
\mathrm{cm}\end{array}$ & $\mathrm{SiO}_{2}$ & $\mathrm{Al}_{2} \mathrm{O}_{3}$ & $\mathrm{Fe}_{2} \mathrm{O}_{3}$ & $\mathrm{R}_{2} \mathrm{O}_{3}$ & MnO & $\mathrm{TiO}_{2}$ & $\mathrm{P}_{2} \mathrm{O}_{5}$ & $\mathrm{SO}_{3}$ & $\mathrm{~K}_{2} \mathrm{O}$ & $\mathrm{Na}_{2} \mathrm{O}$ & $\mathrm{CaO}$ & MgO \\
\hline \multicolumn{13}{|c|}{ Typical gray clayey-loamy soil. Forest } \\
\hline $\begin{array}{l}\text { Ao } \\
0-7\end{array}$ & 74.90 & 12.72 & 2.94 & 15.66 & 0.14 & 0.52 & 0.15 & 0.35 & 1.88 & 2.38 & 0.79 & 1.58 \\
\hline $\begin{array}{c}\text { A1 } \\
20-30\end{array}$ & 73.16 & 12.40 & 4.21 & 16.61 & 0.11 & 0.47 & 0.11 & 0.30 & 2.19 & 2.73 & 1.35 & 1.76 \\
\hline $\begin{array}{c}\mathrm{A} 2 \\
40--50\end{array}$ & 75.18 & 10.40 & 6.40 & 16.80 & 0.12 & 0.38 & 0.09 & 0.39 & 1.62 & 1.83 & 1.26 & 2.00 \\
\hline $\begin{array}{c}\text { B1 } \\
60-70\end{array}$ & 72.63 & 12.10 & 5.85 & 17.95 & 0.13 & 0.41 & 0.09 & 0.30 & 2.35 & 2.27 & 1.30 & 1.63 \\
\hline $\begin{array}{c}\text { B2 } \\
100-110\end{array}$ & 69.30 & 14.06 & 6.34 & 20.40 & 0.14 & 0.40 & 0.05 & 0.29 & 2.51 & 2.83 & 1.56 & 1.68 \\
\hline $\begin{array}{c}\text { B3 } \\
140-150\end{array}$ & 71.35 & 14.41 & 4.68 & 19.09 & 0.14 & 0.38 & 0.07 & 0.20 & 2.57 & 2.88 & 1.77 & 1.18 \\
\hline $\begin{array}{c}\text { BC } \\
190-200\end{array}$ & 69.69 & 13.90 & 6.10 & 20.00 & 0.18 & 0.36 & 0.04 & 0.20 & 3.24 & 3.09 & 1.00 & 1.15 \\
\hline $\begin{array}{c}C \\
410-420\end{array}$ & 71.14 & 11.26 & 7.99 & 19.25 & 0.13 & 0.66 & 0.04 & 0.24 & 2.93 & 2.93 & 0.85 & 1.56 \\
\hline \multicolumn{13}{|c|}{ Typical gray clayey-loamy soil. Arable } \\
\hline $\begin{array}{c}A p \\
0-20\end{array}$ & 77.68 & 13.94 & 4.38 & 18.32 & 0.22 & 0.47 & 0.15 & 0.31 & 0.82 & 1.97 & 1.45 & 1.05 \\
\hline $\begin{array}{c}\mathrm{A} 2 \\
30-40\end{array}$ & 77.50 & 12.04 & 4.14 & 16.18 & 0.14 & 0.38 & 0.09 & 0.30 & 0.96 & 2.19 & 1.22 & 0.93 \\
\hline $\begin{array}{c}B 1 \\
50-60\end{array}$ & 73.07 & 15.13 & 5.17 & 20.30 & 0.09 & 0.41 & 0.06 & 0.28 & 1.06 & 2.17 & 1.40 & 1.43 \\
\hline $\begin{array}{c}\text { B2 } \\
80-90\end{array}$ & 74.26 & 16.70 & 5.40 & 22.10 & 0.13 & 0.52 & 0.08 & 0.18 & 0.90 & 2.19 & 1.44 & 1.30 \\
\hline $\begin{array}{c}\mathrm{BC} \\
110-120\end{array}$ & 75.29 & 13.23 & 4.83 & 18.06 & 0.22 & 0.36 & 0.08 & 0.22 & 1.03 & 2.15 & 0.93 & 1.44 \\
\hline $\begin{array}{c}C \\
190-200\end{array}$ & 74.80 & 14.43 & 4.79 & 19.22 & 0.14 & 0.66 & 0.10 & 0.22 & 0.92 & 2.08 & 1.17 & 1.09 \\
\hline
\end{tabular}

Determination of $\mathrm{Fe}_{2} \mathrm{O}_{3}$ content on genetic soil horizons brings out direction of soilforming process, since the distribution of iron in the soil profile is characteristic for each type of soil. In the investigated soils the vertical distribution of iron oxide has expressive accumulative type, with maximum content in transitive horizon B2 -5.4-6.3\%. In forest virgin gray soils is highlights fallow horizon Ao $-2.94 \%$ and maximum content in the parental rock - by 1.6 times more than in arable soil.

Share of sesquioxides $\left(\mathrm{R}_{2} \mathrm{O}_{3}\right)$, most of which are oxides of iron and aluminum constitute about $16-22 \%$ in investigated gray soils. According to the distribution of sesquioxides in the soil profile are diagnosed soil processes (Table 2).

Titanium The most common form of titanium in the nature is $\mathrm{TiO}_{2}$ dioxide. In the surface soil horizon, the total content of $\mathrm{TiO} 2$ is about $0.50 \%$. Titanium content in the soil profile changes little in many cases, but sometimes increasing in the lower horizons - up to $0.66 \%$ in both soils. 
Phosphorus In both soils phosphorus content in the lower horizons is considerably smaller than in the upper. Most phosphorus in the soil found as organic-phosphorus compounds. In many soils more than half of it's included in these compounds. The phosphorus content of soil humiferous horizons is $0.15 \%$, gradually decreasing to 0.07 in transitive horizon B.

Table 2. Coefficient of eluviation in gray forest and arable soils

\begin{tabular}{|c|c|c|c|c|c|}
\hline Soil & $\begin{array}{l}\text { Genetic } \\
\text { horizon }\end{array}$ & Soil depth, $\mathrm{cm}$ & $\frac{\mathrm{SiO}_{2}}{\mathrm{Al}_{2} \mathrm{O}_{3}}$ & $\frac{\mathrm{SiO}_{2}}{\mathrm{Fe}_{2} \mathrm{O}_{3}}$ & $\frac{\mathrm{SiO}_{2}}{\mathrm{R}_{2} \mathrm{O}_{3}}$ \\
\hline \multirow{8}{*}{$\begin{array}{c}\text { Gray } \\
\text { forest } \\
\text { soil }\end{array}$} & $\mathrm{A} 0$ & $0-7$ & 6 & 25 & 5 \\
\hline & A1 & $20-30$ & 6 & 17 & 4 \\
\hline & A2 & $40-50$ & 7 & 12 & 4 \\
\hline & B1 & $60-70$ & 6 & 12 & 4 \\
\hline & B2 & $100-110$ & 5 & 11 & 3 \\
\hline & B3 & $140-150$ & 5 & 15 & 4 \\
\hline & $\mathrm{BC}$ & $190-200$ & 5 & 11 & 3 \\
\hline & $\mathrm{C}$ & $410-420$ & 6 & 9 & 4 \\
\hline \multirow{6}{*}{$\begin{array}{c}\text { Gray } \\
\text { arable } \\
\text { soil }\end{array}$} & $A p$ & $0-20$ & 6 & 18 & 4 \\
\hline & $\mathrm{A} 2$ & $30-40$ & 6 & 19 & 5 \\
\hline & B1 & $50-60$ & 5 & 14 & 4 \\
\hline & B2 & $80-90$ & 5 & 14 & 3 \\
\hline & $\mathrm{BC}$ & $110-120$ & 6 & 16 & 4 \\
\hline & $\mathrm{C}$ & $190-200$ & 5 & 16 & 4 \\
\hline
\end{tabular}

During the precipitation of sesquioxides, except aluminum, iron, titanium and phosphorus constituting the main mass of the precipitate, a number of other elements are separated from the solution. Their content does not exceed hundredths of a percent, i.e., it is within the accuracy of the weight analysis.

Manganese The content of manganese in gray soils is relatively small compared to the chernozems. The total content of $\mathrm{MnO}$ in the surface soil horizon varies between $0.14-0.22 \%$. The greatest amount of $\mathrm{MnO}$ in the soil profile is confined to the upper horizons, except that in some soils are occasionally manganese-ferrous concretions [7]. Bioaccumulation of manganese oxide can be traced in arable horizon of typical gray soil $(0.22 \%)$.

Potassium in the gray soils is in the mineral form, inaccessible or less accessible for plants. Account minerals, potassium can pass gradually but very slowly in a soluble state under the influence of disaggregation. If low yields of harvests, the release of potassium from mineral compounds can meet the needs of plants, at higher yields and major export of this element from soil, available potassium is insufficient for plant nutrition [8]. The total content of potassium in the soil humiferous horizon is $2 \%$ in virgin gray soil, and $1 \%$ in ploughing gray soil.

Sodium The total content of alkali metal in the soils of the upper horizon is relatively small. The total content of $\mathrm{Na}_{2} \mathrm{O}$ in gray soils constitutes about $2 \%$ and is considered a weak element in researched soils. The content of $\mathrm{Na}_{2} \mathrm{O}$ throughout the soil profile exceeds the content of $\mathrm{K}_{2} \mathrm{O}$.

Sulphur. The surface horizon of gray soil contains $0.30-0.35 \%$ of $\mathrm{SO}_{3}$. In gray soils the sulphur content in the lower horizons of soil is somewhat reduced. Sulfur accumulation in the surface layer of soil due to the biological cycle of the item. Values of sulfur oxides are relatively constant in the soil profile. 
Calcium and Magnesium The surface soil horizon contains $0.79-1.45 \% \mathrm{CaO}$ and 1.58-1.05 MgO. The distribution of calcium in the soil profile depends on the content of carbonates in the soil-forming rock.

Results in percentage of global analysis can be recalculated in different ways depending on the purpose. Recalculations gross data analyses allow to obtain a correct idea of the chemical composition of the mineral part of the soil and to compare it with the composition of the parent rock. This comparison makes possible to detect the presence or absence of minerals destruction and movement, i.e. relative redistribution of the elements in the soil profile, there is need to know for establish the nature of the soil-forming process and determine the type of soil.

To analyze the changes in soil properties is used eluviation coefficient (the ratio of silica and sesquioxides - $\mathrm{R}_{2} \mathrm{O}_{3}$ ), characterizing subsurface weathering. The content of silica on the ratio of sesquioxides shows the increases values in arable gray soil. Total chemical composition reveals a significant departure of most oxides from upper soil profile of arable gray soil.

\section{Conclusions}

Total (global) chemical composition of typical gray clayey-loamy soils as hereditary property of native rock is altered by the action of elementary processes and their use in arable. Modification of chemical composition of the soil horizons can be identified by comparing the total chemical composition of the rocks that have been formed. The mineral part of typical gray soil is composed of silicates and sesquioxides. Share oxides of manganese, titanium, sulfur, phosphorus, potassium and sodium constitute an insignificant part. Typical gray soil use in agriculture led to changes in their chemical composition in the upper horizon (humiferous). The results obtained on the total chemical composition of typical gray soils can be used to control the elementary state soils in agricultural landscapes of the steppe zone of Moldova.To enhance soil fertility of typical gray soils is necessary to applied measures to increase organic matter and remediate structure formation in arable layer, to prevent erosion process and other anthropogenic factors.

\section{References}

[1]. АХТЫРЦЕВ Б.П. (1979). Серые лесные почвы Центральной России. Воронеж: Издво Воронеж. ун-та, 233 с.

[2]. АХТЫРЦЕВ Б.П. (1969). Изменение серых лесных почв среднерусской лесостепи в процессе сельскохозяйственного освоения. Саранск: Морд. гос. ун-т, 163 с.

[3]. ГРАТИ В. П. (1977). Лесные почвы Молдавии и их рациональное использование. Молдавский НИИ почвоведения и агрохимии Н. Димо. Кишинев, 136 с.

[4]. CERBARI, V.; LUNGU, M. (2010). Solurile cenușii (griziomurile) din zona călduroasă semiumedă a Moldovei Centrale. În: Monitoringul calității solurilor Republicii Moldova. Chișinău: Pontos, p. 72-87.

[5]. АРИНУШКИНА Е.В. (1970). Руководство по химическому анализу почв. Изд. 2-е. М: МГУ, с.115-122.

[6]. ПОЛЫНОВ Б. Б. (1944). Валовой почвенный анализ и его толкование. Почвоведение. № 10, с. 482-490.

[7]. РОДИОНОВА, М.Е. (2012). Особенности изменения валового химического состава лесостепных и степных почв в результате их агрогенных трансформаций. В: Фундаментальные исследования. № 3-2, с.333-338

[8]. ПОЧВЫ МОЛДАВИИ. (1984). Генезис, экология, классификация и систематическое описание почв. Т.1. Кишинев: Штиинца, с.173-225. 